\title{
PRODUCTION FACTORS AND ECONOMIC RESULTS OF SMALL FARMS IN SELECTED EUROPEAN UNION COUNTRIES
}

\author{
Andrzej Hornowski ${ }^{1,}$ Pavel Kotyza ${ }^{2}$ \\ ${ }^{1}$ Warsaw University of Life Sciences, Warsaw, Poland, \\ ${ }^{2}$ Czech University of Life Sciences Prague, Prague, Czech Republic
}

\begin{abstract}
The study attempts to assess production factor and the economic performance of small farms in the European Union. A small farm was defined in accordance with the methodology used by Farm Accountancy Data Network (FADN), with economic size from 8 thou. up to 25 thou euro.

The conducted analysis indicates a significant differentiation in the resources possessed (land, labour and capital) and achieved economic and production results. The highest labour productivity (VA/AWU) was achieved by Danish farms (20.7 thousand euros), while the highest rate of asset productivity (0.78) was reached by French farms. In the analysed sample of small farms, the farms with "fieldcrops" orientation prevailed. All analysed production types of small farms, despite significant differences in possessed resources, achieved positive income from farming activities. They were characterized by very low indebtedness of own capital, reached a positive balance of cash from operating activities and performed a negative asset replacement rate.
\end{abstract}

Key words: small farm, FADN, EU, family farm, economic results.

JEL code: Q12, Q14

\section{Introduction}

In agriculture, the farm is considered as a basic unit of agriculture production, in many cases farms have character of family owned business. The discussion on the issue of family farms appears widely in world literature (OECD, FAO, USDA studies) as well as within EU bodies. That fact is proved by increasing number of instruments addressed to family farms (e.g. Drygas M., 2014). Many terms related to the agricultural holdings are in use; terminological diversity results from the specificity of these entities and their functions (e.g. Parzonko A., Hornowski A., 2017). A special group among family farms are farms with a small area or a small economic size. These types of farms dominate on a global scale. In the literature, there is no unambiguous definition of this group of entities (e.g. Zegar J. St., 2012); following terms are used: small-, subsistence-, family-, selfsupply-, peasant-, social- or small scale-farms (e.g. Żmija J., Czekaj M., 2014). For their definition, the authors use a number of different criteria (e.g. What is a small farm?, 2001). The most frequently accepted ones include: the area of agricultural land, the economic size expressed in Economic Size Units (ESU), standard production (e.g. Michalska S., 2012), number of animals, market share or available labour force (AWU) (e.g. Poczta W. and others, 2012). In the European Union, two criteria are most often used for the classification of farms: area and standard production. According to the area, in 2013, there were 10,841 thousand (e.g. Eurostat) farms in the EU. Farms running agricultural activity. Farms up to 5 ha accounted for $65 \%$ of all farms and used only $6 \%$ of UAA of the European Union. Using the criterion of standard production, which determines the income potential of the farm and the possibilities of its development, small farms (up to 25,000 euros) accounted for $82 \%$ of all EU farms in 2013 and used $23 \%$ of UAA. As the European structure of agriculture is very heterogeneous, general differences among the European farms were observed by various authors (e.g. Svoboda J. and others, 2016; Spicka J., 2014; Trnkova G., MALA, Z. 2013; Hornowski A., Kotyza P., 2017). But small farms were not always among their interest. Also since small farms are numerously important, receive significant portion of CAP payments and still employ large amount of people, their economic performance is not always assessed in literature. From that perspective, main aim of the contribution is to assess differences in used production factors (capital, labour, land) and economic performance of small 
farms in the EU countries. Based on above formulated aims, research questions were formulated. Q1: Are there significant differences among EU small farms in their access and utilisation of production resources? Q2: Is availability of resources connected to main farming activity?

\section{Materials and methods}

The article attempts to characterize small farms in the European Union. For the purpose of this article, small farm is characterised in accordance with the rules applicable in FADN based on economic size; i.e. enterprises between 8.000 and 25.000 euro of standard output (SO). The economic size of an agricultural holding is defined as the sum of the values of standard output of all agricultural activities on the farm, which is expressed by the value in euro. In the first part of the article, data on average small farms in the EU countries are analysed. Small farms from Belgium, Germany, Luxembourg, the Netherlands and Slovakia were not included in the analysis due to the lack of data in the European FADN. In the second part of the article, an analysis was made to compare different production types of small farms.

The following information and indicators were used in the economic and production analysis of European small farms: (i) net value added per full-time employed in EUR / AWU; (ii) income from a family farm per full-time employed person in EUR / FWU; (iii)share of subsidies in farm income; (iv) total production per 1 ha of UAA in EUR/ha; ( $v$ ) production profitability (Total output / Total input); (iv) asset productivity (total production over total assets); (vii) productivity of fixed capital expenditures (total production over depreciation); (viii) Debt-equity Ratio (total debt over equity); (ix) assets/AWU ( $x$ ) cash flow $\mathrm{I}$; (xi) fixed assets replacement rate.

The cash flow balance from operating activities (Cash Flow I) is calculated as revenues less expenses of operating activities in the accounting year. Fixed assets replacement rate is calculated as net investment value to the total amount of fixed assets and informs about the degree of property reproduction. The values between 0 and $0.99 \%$ indicate straight reproduction, negative values inform about negative reproduction, and the values above $1 \%$ indicate extended replacement (e.g. Jozwiak W., 2013).

The contribution was based on most recent data from Eurostat (2007-2013) and from the EU-wide FADN (2007-2015).

\section{Research results and discussion}

According to the Eurostat data, the number of small farms in 2013 (with less than 25,000 euro of SO) decreased by 4 percentage points in comparison with 2007. A very high share of small farms in the total number of farms makes them an extremely heterogeneous over the whole Europe. Differences of selected features among small farms in the EU countries are presented in Table 1.

On average, the analysed farms had an area of 14.51 ha of agricultural land. The highest UAA was occupied by small farms in the United Kingdom (47.36 ha), Estonia (37.15 ha) and Sweden ( $36.41 \mathrm{ha}$ ), while the lowest UAA farms are found in Malta (2.44 ha). Thus, the difference between the smallest and largest farms was $44.92 \mathrm{ha}$. The highest production per 1 ha of UAA was achieved by French $(9,916$ EUR) and Malta $(6,145)$ farms. While farms in France and Malta are the smallest among other countries. France farms focus mainly on field crop production, while Maltese farmers depends on horticulture. In the countries, where proportion of small farms is the biggest, the production per 1 ha of UAA was usually below 1,000 EUR (UK, FI, LV, IE, EE, CZ). 
As it can be found in Table 1, only in three countries (DK, ES, FR) agricultural farms covered by the study showed labour productivity measured by net value added per full-time person (AWU) exceeding 15 thousand euro. The value of this measure was very diverse and fluctuated in the analysed group of farms in the range from 2.7 thousand euro (Slovenia) to 20.7 thousand euro (Denmark). The lowest level of labour productivity (less than EUR 4,000 per AWU) was characteristic for the countries of Central and Eastern Europe.

Table 1.

Selected information about small farms, 2015

\begin{tabular}{|c|c|c|c|c|c|c|c|}
\hline \multicolumn{8}{|c|}{ Economic size $8000-<25000$ EUR } \\
\hline & 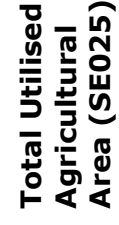 & 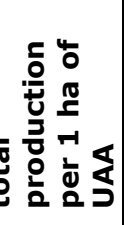 & 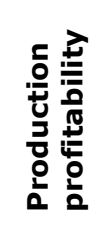 & 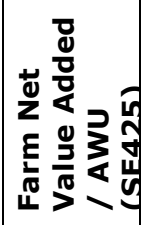 & 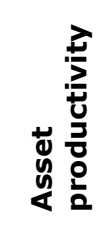 & 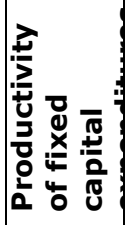 & Dominant farming type \\
\hline BG & 13.82 & 1,174 & 1.22 & 7,098 & 0.37 & 9.51 & Fieldcrops (35 \%) \\
\hline $\mathbf{C Y}$ & 8.11 & 2,068 & 1.08 & 5,827 & 0.14 & 6.81 & Other permanent crops (43\%) \\
\hline $\mathbf{C Z}$ & 24.97 & 792 & 0.84 & 5,767 & 0.17 & 3.24 & Fieldcrops and Other permanent crops (32 \%) \\
\hline DK & 18.01 & 4,077 & 0.89 & 20,723 & 0.11 & 6.31 & Fieldcrops (49 \%) \\
\hline GR & 7.96 & 2,220 & 1.28 & 10,211 & 0.16 & 5.00 & Other permanent crops (40 \%) \\
\hline ES & 22.56 & 1,187 & 1.51 & 17,779 & 0.14 & 8.78 & Other permanent crops $(40 \%)$ \\
\hline EE & 37.15 & 495 & 0.88 & 6,398 & 0.26 & 5.81 & Fieldcrops (36 \%) \\
\hline $\mathbf{F R}$ & 5.31 & 9,916 & 1.16 & 18,998 & 0.78 & 14.09 & Fieldcrops (69 \%) \\
\hline HR & 11.74 & 1,444 & 1.15 & 3,792 & 0.11 & 4.41 & Mixed $(28 \%)$ \\
\hline HU & 20.58 & 949 & 1.25 & 12,530 & 0.22 & 11.67 & Fieldcrops (52 \%) \\
\hline IE & 32.59 & 626 & 0.92 & 9,626 & 0.03 & 8.06 & Other grazing livestock (94\%) \\
\hline IT & 8.88 & 2,246 & 1.52 & 13,328 & 0.10 & 7.73 & Other grazing livestock (38 \%) \\
\hline LT & 30.75 & 472 & 0.87 & 4,241 & 0.21 & 3.01 & Milk (37\%) \\
\hline LV & 30.41 & 505 & 0.97 & 5,120 & 0.32 & 7.06 & Milk and Mixed (33\%) \\
\hline MT & 2.44 & 6,145 & 1.54 & 6,241 & 0.13 & 10.38 & Horticulture $(50 \%)$ \\
\hline AT & 14.65 & 2,044 & 0.91 & 7,387 & 0.10 & 2.85 & Other grazing livestock (49\%) \\
\hline PL & 13.47 & 1,085 & 1.09 & 3,705 & 0.11 & 3.96 & Mixed $(40 \%)$ \\
\hline PT & 13.8 & 1,184 & 1.41 & 9,186 & 0.22 & 5.74 & Other grazing livestock (30 \%) \\
\hline RO & 8.83 & 1,580 & 1.53 & 5,319 & 0.36 & 11.28 & $\begin{array}{l}\text { Other grazing livestock and Mixed }(29 \% \times 2= \\
58 \%)\end{array}$ \\
\hline $\mathbf{F I}$ & 31.94 & 749 & 0.59 & 4,656 & 0.11 & 2.38 & Fieldcrops (96 \%) \\
\hline SE & 36.41 & 1,371 & 0.85 & 12,549 & 0.12 & 5.77 & Other grazing livestock (63 \%) \\
\hline SI & 9.16 & 2,067 & 0.92 & 2,743 & 0.09 & 2.77 & Other grazing livestock (38 \%) \\
\hline UK & 47.36 & 586 & 0.72 & 8,157 & 0.04 & 3.45 & Other grazing livestock (98 \%) \\
\hline Total & 14.51 & 1,319 & 1.24 & 8,504 & 0.12 & 5.81 & Fieldcrops (30 \%) \\
\hline
\end{tabular}

Lower volatility was observed in the asset productivity, which ranged from 0.03 up to 0.78 (Table 1). Farmers in Ireland (.1), the United Kingdom (.04) and Slovenia (.09) held the least productive assets. Ireland and the United Kingdom are characterised as countries with of the highest amount of assets, land and labour, which resulted into such low values of above-mentioned indicator (below 0.1). The most productive assets were owned by French farms (more than $2 x$ higher productivity than Danish farms), reaching asset productivity at the level of 0.78 . Average French farm from the FADN observation is characterized by low value of UAA and by low capital intensity per one AWU (below EUR 55 thousand per AWU). For farm development opportunities, it 
is important whether and to what extent farms invest in renewal of fixed assets and what is the effectiveness of the capital resources involved in production. This efficiency could be measured by productivity of fixed capital expenditures calculated as production value over depreciation. In the most efficient farms, the productivity exceeded 10 (FR - 14; HU - 11.6; RO -11.2; MT - 10.38). Maltese farmers, although have very limited area available, can reach high production profitability and they also evince investments into the horticultural production which is considered to be capital and labour intensive. Farms in Finland (2.38), Slovenia (2.77) and Austria (2.85) proved to be the least effective.

Table 3 informs about average annual income of a single person, without children with $100 \%$ of average wage, in selected counties of the EU. As the table indicates, the lowest income is reached in Bulgaria and Romania, while Sweden and Austria are located on the opposite side of the scale. Family farm income to one family labour unit (SE430) express net remuneration per one family member.

Table 2.

Family farm income as a share of average income, selected EU countries, 2015

\begin{tabular}{|l|c|c|c|c|c|c|c|c|}
\hline \multicolumn{1}{|c|}{$\mathbf{2 0 1 5}$} & BG & CY & CZ & DK & GR & ES & EE & FR \\
\hline $\begin{array}{l}\text { Family farm income/FWU } \\
\text { (SE430) }\end{array}$ & 8,054 & 4,559 & 6,257 & $-5,893$ & 9,693 & 17,095 & 5,180 & 15,355 \\
\hline Annual average Income & 6,579 & N/A & 15,617 & 54,881 & 25,046 & 34,391 & 17,454 & 51,905 \\
\hline $\begin{array}{l}\text { Farmers income to average } \\
\text { income }\end{array}$ & $123 \%$ & N/A & $40 \%$ & $-11 \%$ & $39 \%$ & $50 \%$ & $30 \%$ & $30 \%$ \\
\hline & HR & HU & IE & IT & LT & LV & MT & AT \\
\hline $\begin{array}{l}\text { Family farm income/FWU } \\
\text { (SE430) }\end{array}$ & 3,474 & 14,104 & 9,477 & 12,417 & 4,810 & 4,712 & 6,094 & 4,772 \\
\hline Annual average Income' & 14,612 & 13,149 & 38,401 & 40,488 & 11,296 & 11,854 & 22,451 & 56,614 \\
\hline $\begin{array}{l}\text { Farmers Income to average } \\
\text { income }\end{array}$ & $24 \%$ & $107 \%$ & $25 \%$ & $31 \%$ & $43 \%$ & $40 \%$ & $27 \%$ & $3 \%$ \\
\hline & $\mathbf{P L}$ & $\mathbf{P T}$ & $\mathbf{R O}$ & $\mathbf{F I}$ & $\mathbf{S E}$ & $\mathbf{S I}$ & UK & TOTAL \\
\hline $\begin{array}{l}\text { Family farm income/FWU } \\
\text { (SE430) }\end{array}$ & 3,417 & 10,294 & 5,257 & -28 & 4,447 & 2,811 & 6,463 & 7,926 \\
\hline Annual average Income' & 13,766 & 21,406 & 3,427 & 53,104 & 59,203 & 21,005 & 54,926 & 42,531 \\
\hline $\begin{array}{l}\text { Farmers Income to average } \\
\text { income }\end{array}$ & $25 \%$ & $43 \%$ & $62 \%$ & $-0.1 \%$ & $3 \%$ & $13 \%$ & $12 \%$ & $19 \%$ \\
\hline
\end{tabular}

Note: 1 - Annual average income - annual net earnings, single person without children, $100 \%$ of AW Source: authors' processing. based on EUROSTAT and European FADN data

The Table 3 indicates, that only in Bulgaria and Hungary family income per one person is comparable with average annual salary. It means that farmers are able to reach income comparable to national average and therefore it can be concluded, that they can live only from the farming activities, without additional income. On the other hand, in other EU countries, farming activities do not generate enough income to fulfil needs of farmers. Farmers income to average income ranges from $8 \%$ in Sweden and Austrian, to $62 \%$ in Romania, with an average of about $19 \%$. Special case can be observed in Denmark and Finland, where farm net income is negative and therefore farming activities needs to be subsidised by farmers from other non-agricultural activities.

Above presented selected indicators and economic and production measures show that small farms defined by economic size from 8 to 25 thousand euro of standard output is a strongly heterogeneous group of farms. Differences between farms in individual countries were mainly 
caused by differences in dominating farming types in individual countries. The analysis of farming types is presented in Table 3.

Table 3.

Selected features characterizing types of small farms in EU. latest data 2015

\begin{tabular}{|c|c|c|c|c|c|c|c|c|c|}
\hline 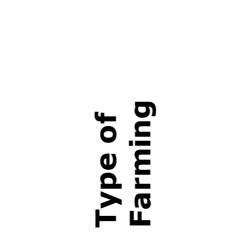 & $\begin{array}{l}\frac{n}{0} \\
\frac{0}{0} \\
\frac{0}{0} \\
\frac{0}{4}\end{array}$ & 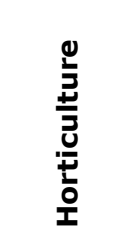 & 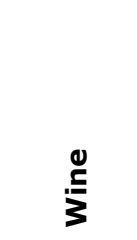 & 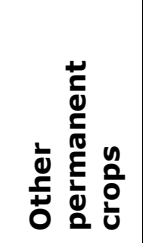 & $\stackrel{\check{E}}{\bar{\Sigma}}$ & 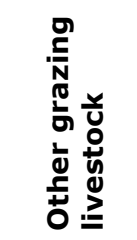 & $\begin{array}{l}y \\
\frac{1}{0} \\
\frac{2}{c} \\
\frac{0}{0}\end{array}$ & $\frac{\underset{\mathbb{d}}{x}}{\frac{x}{\Sigma}}$ & $\begin{array}{l}\bar{J} \\
\stackrel{0}{\circ} \\
\end{array}$ \\
\hline Structure [ \%] & 30 & 3 & 6 & 19 & 7 & 17 & 1 & 17 & 100 \\
\hline $\begin{array}{l}\text { Total labour } \\
\text { input (SE010) }\end{array}$ & 1.06 & 1.51 & 0.97 & 1.14 & 1.45 & 1.24 & 1.21 & 1.36 & 1.19 \\
\hline $\begin{array}{l}\text { Total Utilised } \\
\text { Agricultural } \\
\text { Area (SE025) }\end{array}$ & 18.92 & 2.31 & 7.23 & 9.38 & 12.14 & 19.92 & 6.28 & 12.38 & 14.51 \\
\hline $\begin{array}{l}\text { Total assets } \\
\text { (SE436) }\end{array}$ & 17,5023 & 96,548 & 140,265 & 166,181 & 113,763 & 227,466 & 71,781 & 103,078 & 160,946 \\
\hline \multicolumn{10}{|l|}{ Assets/AWU } \\
\hline $\begin{array}{l}\text { [thou } \\
\text { euro/AWU] }\end{array}$ & 165.12 & 63.94 & 144.6 & 145.77 & 78.46 & 183.44 & 59.32 & 75.79 & 135.25 \\
\hline $\begin{array}{l}\text { Fixed assets } \\
\text { replacement } \\
\text { rate }[\%]\end{array}$ & -0.92 & -1.14 & -1.71 & -0.81 & -1.19 & -0.22 & -2.97 & -0.98 & -0.79 \\
\hline $\begin{array}{l}\text { Total output } \\
\text { (SE131) }\end{array}$ & 19,203 & 27,763 & 18,851 & 23,712 & 14,723 & 19,564 & 17,463 & 14,295 & 19,140 \\
\hline $\begin{array}{l}\text { Total Inputs } \\
\text { (SE270) }\end{array}$ & 17,065 & 17,594 & 11,420 & 14,647 & 13,212 & 18,254 & 14,615 & 12,342 & 15,409 \\
\hline $\begin{array}{l}\text { Profitability of } \\
\text { production } \\
\text { index (SE132) }\end{array}$ & 1.13 & 1.58 & 1.65 & 1.62 & 1.11 & 1.07 & 1.19 & 1.16 & 1.24 \\
\hline $\begin{array}{l}\text { Farm Net } \\
\text { Value Added / } \\
\text { AWU (SE425) }\end{array}$ & 9,122 & 9,273 & 11,688 & 14,292 & 4,112 & 7,685 & 3,919 & 4,355 & 8,504 \\
\hline $\begin{array}{l}\text { Farm Net } \\
\text { Income } \\
\text { (SE420) }\end{array}$ & 7,910 & 11,066 & 9,589 & 12,898 & 5,551 & 8,562 & 4,282 & 5,478 & 8,521 \\
\hline $\begin{array}{l}\text { Balance } \\
\text { current } \\
\text { subsidies \& } \\
\text { taxes (SE600) }\end{array}$ & 5,717 & 535 & 2,091 & 3,976 & 3,973 & 7,048 & 1,364 & 3,410 & 4,726 \\
\hline $\begin{array}{l}\text { Share of } \\
\text { subsidies in } \\
\text { farm income } \\
{[\%]}\end{array}$ & 72.3 & 4.8 & 21.8 & 30.8 & 71.6 & 82.3 & 31.9 & 62.2 & 55.5 \\
\hline $\begin{array}{l}\text { Farm Net } \\
\text { Income } \\
\text { without } \\
\text { subsidies }\end{array}$ & $-3,579$ & 9,634 & 5,340 & 5,089 & $-2,462$ & $-5,738$ & 1,484 & $-1,457$ & -995 \\
\hline $\begin{array}{l}\text { Family Farm } \\
\text { Income / FWU } \\
\text { (SE430) }\end{array}$ & 8,175 & 9,317 & 11,729 & 14,655 & 3,968 & 7,381 & 3,767 & 4,136 & 7,926 \\
\hline $\begin{array}{l}\text { Debt-equity } \\
\text { Ratio [ \%] }\end{array}$ & 3 & 3 & 2 & 1 & 2 & 4 & 4 & 3 & 3 \\
\hline $\begin{array}{l}\text { Cash Flow } 1 \\
\text { (SE526) }\end{array}$ & 11,050 & 13,298 & 12,174 & 15,765 & 8,007 & 10,686 & 6,562 & 7,591 & 11,146 \\
\hline
\end{tabular}


In the surveyed European countries, the largest share in the structure of small farms were farms with the "fieldcrops" type of agricultural production. Holdings of this type together with other "grazing livestock" farms were characterized by the largest UAA (less than 20 ha) and reached the highest values in Assets to AWU indicator (over 160). The "horticultural" farms occupied the smallest area of UAA, and their share in the structure of all small farms was only $3 \%$. Farms of this type were characterized by the highest input of labour (1.51 AWU) and at the same time achieved one of the lowest values of assets to AWU at the level of 63,940 EUR/AWU. The smallest number of farms were among farms producing mainly granivores $(1 \%)$. They were characterized by average labour input in total (1.21), low UAA ( 6.28 ha; more than 2 times less than the average for the surveyed group of farms) and the lowest value of assets to labour (59.32). All farm groups were characterized by a negative fixed assets replacement rate, which proves that these farms are unable to maintain value of their existing fixed assets.

Only horticulture farms and other permanent crop farms reached total production exceeding 20,000 euro. The highest work efficiency, measured by net value added per AWU, reached farms producing other permanent crops (14,292 euro/AWU), while the lowest values reached farms producing Granivores (3,919 euro/AWU), which accounted for $27 \%$ of the highest value. All farms evinced profitability, but only horticultural, wine and other permanent crop farms reached profitability (SE132) above 1.5 .

The highest agricultural income as well as income per one full-time employee (measured by AWU) were generated by farms producing other permanent crops. For comparison, among those farms, agricultural income and income per one AWU was 3 time and 4 time higher than in Granivores. Farm subsidies played a very important role among all surveyed of farms. In half of the analysed farms types, the share of subsidies in income exceeded $50 \%$. This means that without subsidies farms these farms would have a negative financial result (valid for field crops farms; milk farms; other grazing livestock farms and mixed farms). The highest share of subsidies in income was observed in Other grazing livestock farms, where subsidies created about $82 \%$ of total income. This largely makes these farms dependent on external factors (help). Least subsidy dependent were farms focusing on Horticulture (4.8\%), followed by wine producing entities (21.8). Horticulture farms also evince highest farm net income without subsidies, in 2013 it was 9,634 euro, followed by wine (5,340 euro) and other permanent crops farms (5,089 euro).

All farms surveyed. regardless of the production direction. achieved high profitability of production (subsidies included). Indebtedness in all types of surveyed farms was relatively small, not exceeding $4 \%$, so it does not pose a threat to farm financial security. In all the farms surveyed, the cash flow from operating activities was positive, which means that households generated savings on operating activities.

\section{Conclusions}

1) The conducted analysis indicates a significant diversification of economic and production results as well as available resources (land, labour, capital) in the group of small farms from selected EU countries (Q1). The highest labour productivity (VA/AWU) was achieved by Danish farms (20.7 thousand euros), while the highest rate of asset productivity (0.78) was reached by French farms. In the analysed sample of small farms, the farms with "fieldcrops" orientation prevailed (30\% of all farms surveyed). 
2) The highest profitability of production was achieved by farms with orientation toward other permanent crops (54\%). Among these farms, the share of subsidies on total income reached the highest value $-82 \%$. The share of subsidies on total incomes exceeded $50 \%$ also in fieldcrops, milk and mixed farms. The above-mentioned farms' types would have achieved a negative financial result without subsidies. The highest income per one full-time employee was reached by other permanent crops farms (14,655 euros/FWU), while the lowest income was evinced among Granivore farms (3,767 euros/FWU). (Q2)

3) All analysed production types of small farms, despite significant differences in possessed resources, achieved positive income from farming activities. They were characterized by very low indebtedness of own capital and reached a positive balance of cash from operating activities. All farm production types were characterized by a negative asset replacement rate; that fact may lead to problems in the future, as fixed capital is not being replaces continuously.

4) It should be taken in consideration that in the FADN database occur only farms conducting production that is intended for sale. In addition, the FADN standard results only contain information on agricultural activities carried out on farms, whereas no information is recorded about revenues from non-agricultural activities. Owners of small farms, due to incomplete use of their labour resources on their own farms, often take up full- or part-time work outside the farm. Usually the farm is run by one person and his/her spouse works outside the farm, while income earned is shared and combined (both income from the farm and from outside the farm may be used for the farm operation or vice versa). Therefore, by focusing exclusively on FADN data, it is not possible to obtain a real picture of the situation of small farms in the whole EU.

\section{Acknowledgements}

This contribution was supported from funds provided by National Science Centre Poland under project no. UMO-2015/17/N/HS4/01550.

\section{Bibliografia}

1. Drygas, M. (2014). Mozliwosci okreslenia definicji gospodarstwa rodzinnego (Possibilities to determine the definition of a family farm).

Retrieved from: www.senat.gov.pl. Access date 06.01.2018 r.

EUROSTAT. http://ec.europa.eu/eurostat/data/database. Access date 06.01.2018 r.

2. Józwiak, W. (2003). Przewagi komparatywne polskich gospodarstw rolniczych (Comparative advantages of Polish farms), IERiGŻ, Warszawa.

3. Parzonko, A. Hornowski, A. (2017). Economic and Social Assessment of the Use of Structural Funds in the Creation of the Development of "Small" Farms in Poland. Journal of Agribusiness and Rural Development, $\mathrm{nr}$ 2. s. 413-420.

4. Poczta. W., Czubak. W., Kiryluk-Dryjska, E., Sadowski, A., Siemiński, p. (2012). Koncepcja ukierunkowania wsparcia gospodarstw rolnych w perspektywie 2014-2020 (The concept of targeting farm support in the 2014-2020 perspective). Ekspertyza wykonana dla MRiRW w Warszawie.

5. Michalska, S. (2012). Społeczny wymiar funkcjonowania drobnych gospodarstw rolnych (Social aspects of the functioning of small farms). Problemy Drobnych Gospodarstw Rolnych, nr 1. ss. 85-94.

6. What is a small farm?. "Agricultural Economics Briefs". (2001). No. 2- July.

7. Zegar, J. St. (2012). Współczesne wyzwania rolnictwa (Contemporary agriculture challenges). PWN, Warszawa, str. 106.

8. Zegar, J. S. (2012). Rola drobnych gospodarstw rolnych w procesie społecznie zrównoważonego rozwoju obszarów wiejskich (The role of small farms in the socially sustainable development of rural areas). Problemy Drobnych Gospodarstw Rolnych, nr 1. ss. 129-148.

9. Svoboda. J.. Lososová. J. and Zdenek. R. (2016). "Subsidies on Investments in the EU Member States". AGRIS on-line Papers in Economics and Informatics. Vol. 8. No. 4. pp. 153 - 162. ISSN 1804-1930. DOI 10.7160/aol.2016.080414.

10.Spicka. J. (2014). The Regional Efficiency of Mixed Crop and Livestock Type of Farming and Its Determinants. Agris on-line Papers in Economics and Informatics. 6(1). 99-109. 
Proceedings of the 2018 International Conference "ECONOMIC SCIENCE FOR RURAL DEVELOPMENT" No 47

Jelgava, LLU ESAF, 911 May 2018, pp. 100-107 DOI 10.22616/ESRD.2018.011

11. TRNKOVA, G. MALA, Z. (2013). Analysis of Inequality of Gross Added Value of Conventional And Organic Farms in Selected EU Countries. Acta Universitatis Agriculturae et Silviculturae Mendelianae Brunensis. LXI. No. 7. pp. 2883-2891. 